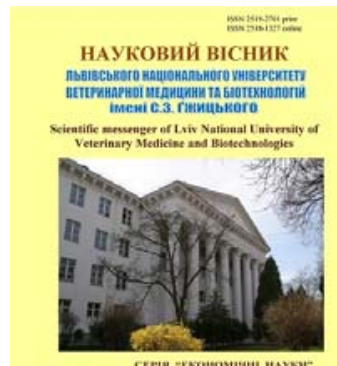

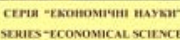 ветеринарної медицини та біотехнологій імені С.3. Гжицького. Серія: Економічні науки

\author{
Scientific Messenger of Lviv National University \\ of Veterinary Medicine and Biotechnologies. \\ Series: Economical Sciences
}

UDC 368.97

\section{Insurance of tourist activity in Ukraine}

\author{
O. Dadak ${ }^{1}$, M. Dorosh-Kizym ${ }^{1}$, R.S. Grabovsky ${ }^{1}$, R.P. Dudiak ${ }^{2}$ \\ ${ }^{1}$ Stepan Gzhytskyi National University of Veterinary Medicine and Biotechnologies Lviv, Ukraine \\ ${ }^{2}$ Lviv National Agrarian University, Lviv, Ukraine
}

Article info

Received 05.02.2019

Received in revised form 06.03 .2019

Accepted 07.03.2019

Stepan Gzhytskyi National University of Veterinary Medicine and Biotechnologies Lviv, Pekarska Str., 50, Lviv, 79010, Ukraine. Tel.: +38-050-550-51-11 E-mail:tarikoxi@bigmir.net

Lviv National Agrarian University, Volodymyr Velykyi Str., 1 , Dubliany, Lviv, 80381, Ukraine.

Dadak, O., Dorosh-Kizym, M., Grabovsky, R.S., \& Dudiak, R.P. (2019). Insurance of tourist activity in Ukraine. Scientific Messenger of Lviv National University of Veterinary Medicine and Biotechnologies. Series: Economical Sciences, 21(92), 115-119. doi: 10.32718/nvlvet-e9219

At present, tourism insurance is in high demand in Ukraine, as there has been a big tendency in recent years to increase the number of people traveling abroad. The reason for such growth in the tourism sector is primarily due to a change in the way of life of Ukrainian citizens, the adoption of a visa-free regime, adequate prices for rest and quality of service provision in comparison with domestic ones. The modern insurance market offers a large assortment of insurance products, which enables it to integrate with other sectors of the economy. Tourist activity in its economic nature is characterized by a high degree of riskiness, and therefore its effective functioning is impossible without insurance. All developed countries have long introduced insurance in the tourist market for the successful functioning of this industry and the state economy as a whole. The issue of insurance in tourism in the Ukrainian market is problematic, as it is characterized by low awareness and trust in the population, insufficient attention from the state authorities. Insurance and tourism are of great importance for the development of the economy. The growth of the dynamics of international tourist flows requires the strengthening of the quality requirements of tourist services and the existence of the insurance market. Insurance of tourism industry is a new type of insurance in Ukraine, the study and analysis of the problems of this type of insurance is not perfect and little studied by domestic scientists, in contrast to foreign ones. The tourism industry always has a certain danger to the life of both tourists and its employees. Natural disasters, accidents and other unforeseen events can affect the balanced activities of the tourist complex. After all, with the development of scientific and technological progress, the natural and industrial-economic cataclysms are not decreasing, but on the contrary increasing. In order to ensure the stable operation of travel companies and to ensure quality recreation for tourists in various areas of high risk, there are various risk management tools, one of which is insurance. Insurance as a component of the security system in the tourism industry helps to stabilize the activity of tourism enterprises and tour operator companies, as well as safety of tourist trips both in Ukraine and abroad.

Key words: insurance, insurance activity, tourism industry, tourist insurance, tourism industry, insurance policy, insurance contract.

\section{Страхування туристичної діяльності в Україні}

\author{
О.О. Дадак ${ }^{1}$ М.М. Дорош-Кізим ${ }^{1}$, Р.С. Грабовський ${ }^{1}$, Р.П. Дудяк ${ }^{2}$ \\ ${ }^{1}$ Львівський національний університет ветеринарної медицини та біотехнологій імені С.3. Гжицького, \\ м. Львів, Україна \\ ${ }^{2}$ Львівський національний аграрний університет, м. Львів, Україна
}

В теперішній час в Украӥні користується великим попитом туристичне страхування, адже за останні роки спостерігається велика тенденція збільшення кількості осіб, які подорожують за кордон. Причина такого росту у сфері туризму в периу чергу пов 'язана із зміною способу життя украӥнських громадян, прийняттям безвізового режиму, адекватними цінами на відпочинок та якістю надання послуг в порівнянні з вітчизняними. Сучасний ринок страхування пропонує великий асортимент страхових продуктів, завдяки яким він має можливість інтегруватися з іншими галузями економіки. Туристична діяльність за своєю економічною 
природою характеризується високим ступенем ризиковості, а тому ї̈ ефективне функиіонування неможливе без страхування. Усі розвинуті країни вже давно запроваджують страхування на туристичному ринку для успішного функціонування даної галузі та державної економіки в цілому. Питання страхування в туризмі на українському ринку є проблемним, оскільки відрізняється низькою проінформованістю та довірою населення, недостатньою увагою з боку державних органів. Страхування і сфера туризму мають велике значення для розвитку економіки. Зростання динаміки міжнародних туристичних потоків вимагає посилення вимог якості туристичних послуг та існування страхового ринку. Страхування туристичної галузі - це новий вид страхування в Украӥні, то вивчення і аналіз проблематики такого виду страхування не є досконалим і мало вивчений вітчизняними науковцями, на відміну від зарубіжних. Туристична галузь завжди несе в собі певну небезпеку для життєдіяльності як самих туристів, так і ї̈ працівників. Стихійні лиха, нещасні випадки та інші непередбачені подї можуть порушити збалансовану діяльність туристичного комплексу. Адже з розвитком науково-технічного прогресу природні і виробничо-господарські катаклізми не змениуються а навпаки збільиуються. Для забезпечення стабільної діяльності туристичних компаній та гарантування якісного відпочинку туристам, у різних сферах підвищеного ризику, існують різні інструменти управління ризиком, одним з яких є страхування. Страхування як складова системи безпеки в туристичній індустрї сприяє стабілізації діяльності туристичних підприємств та туроператорських фірм, а також безпеці туристичних подорожей як в Украӥні, так і за ї̈ межами.

Ключові слова: страхування, страхова діяльність, туристична галузь, турист, страхування туристичної галузі, страховий поліс, договір страхування.

\section{Вступ}

Страхування туристів, здійснюється відповідно до норм Закону України "Про туризм", а також на вимогу посольств при відкритті візи. Згідно зі ст.16 Закону України "Про туризм", страхування туристів (медичне та від нещасного випадку) при здійсненні туристичних поїздок $\epsilon$ обов'язковим i забезпечується суб'єктами туристичної діяльності на основі угод із страховиками.

Туристична подорож несе у собі багато несподіванок, адже може стати жертвою катастрофи або пограбування, раптово захворіти, внаслідок зміни погоди та інших обставин можуть не виправдатися його сподівання на спокійний відпочинок. У цих і в безлічі інших випадків виникне: необхідність наперед забезпечити себе від їхніх шкідливих наслідків або звести їх до мінімуму.

Також працівники туристичної індустрії знаходяться в зоні підвищеного ризику. Під час прийняття ix на роботу відповідні відомства та саме туристичне підприємство повинні прийняти на себе зобов'язання щодо страхування їх життя та здоров'я. Останніми роками відчувається помітне зростання кількості страхових випадків, особливо тяжких на дорогах, включаючи летальні випадки і необхідність репатріації тіла на батьківщину.

Аналіз останніх досліджень і публікацій. Актуальність даного дослідження знаходить своє відображення у численних наукових працях українських і зарубіжних вчених. Вивченням питання страхування туристичної галузі в Україні займаються такі науковці, як О.О. Охріменко, Н.М. Власова, К.О. Вейнберг, А.В. Кошляк, Є.В. Бєляєва, Ю.В. Чмир, Д.Р. Абрамітова, Л.М. Гайдукевич, И.В. Зорин, М.М. Маринин, М.С. Клапків, Ю.М. Клапків, М.П. Мальська, Н.В. Антонюк, М.В. Мних, I.М. Школа та ін. (Sirik, 2006; Aleksandrova, 2008; Marinin, 2008).

Формулювання циілей статті полягає в дослідженні напрямку розвитку туристичного страхування, доцільності i необхідність включення додаткових послуг в туристичний страховий поліс. Страховий поліс $\epsilon$ невід'ємною складовою якісного туристичного продукту. Розуміння важливості туристичного страхування $\epsilon$ ознакою високої страхової культури туристичного оператора, страховика і самого туриста.

\section{Результати та їх обговорення}

Сьогодні ситуація у ряді традиційно туристичних країн $€$ неспокійною. Одна 3 причин - брак культури поведінки туристів за кордоном. Вирішенню цієї проблеми могло б сприяти проведення туристичними фірмами $з$ клієнтами докладного інструктажу перед виїздом. Звичайно, ніхто не застрахований від випадковостей. Але деяких неприємностей, що відбуваються з клієнтами, можна запобігти. Закон України "Про страхування" регулює відносини у сфері страхування і спрямований на створення ринку страхових послуг, посилення страхового захисту майнових інтересів, зокрема туристів, а також туристичних підприємств та їх працівників.

Програми страхування, які розробляються для туристів, що виїзджають за кордон - один з іміджевих видів програм страхування.

Більше всього страхових подій відбувається в тих країнах, куди частіше за все їздять туристи. Для пляжного відпочинку українці і надалі обирають курорти Єгипту, Туреччини, Іспанії, Італії і Греції. В зимовий період гірськолижні курорти Австрії, Польщі і Чехії. Проте найбільш небезпечними курортами світу залишаються курорти Таїланду, Індії, Південної Африки і Куби. Ці країни характеризуються жахливою антисанітарією, харчовими отруєннями, інфекціями, вірусами, венеричними захворюваннями, високим рівнем злочинності, хижою підводною фауною (скати, акули i інші) i тропічними отруйними комахами i т.д.

Відповідно $з$ точки зору тероризму і військових дій самими небезпечними країнами $є$ Сомалі, Пакистан і Ірак. А останнім часом найбільше зростання терористичних загроз спостерігається в Ірані, Лівії, Уганді, Єгипті, Нігерії і Смені. Тому на сьогодні не кожна страхова компанія пропонує страхові програми для цих країнах. Звичайно, такі перспективи примушують змінити плани багатьох туристів $\mathrm{i}$ зробити вибір на користь відпочинку в країнах Європи та України.

Проте, як показує практика протягом останніх років частіше за все страждають туристи від травм, одержаних на гірськолижних курортах Польщі, Франції, Чехії, Австрії, та України. Проте європейський рівень якості надання медичної допомоги і робота ассистанса, полегшує врегулювання страхових подій. 
Треба визнати, що страхові програми для туристів, що виїжджають за кордон, - $\epsilon$ перспективним напрямом діяльності українських туристичних фірм. Страхування в туризмі - це система відносин між страховою компанією i туристом по захисту його життя i здоров'я та майнових інтересів при настанні страхових випадків.

Основними сторонами цих відносин є страховики (страхові компанії), страхувальники (туроператори i турагенти) і туристи, які виїжджають за кордон.

В Україні відносини страхування законодавчо нормуються: Законом України "Про страхування", Законом України "Про туризм” і низкою інших документів. Згідно зі ст. 17 Закону України "Про туризм", страхування туристів (медичне та від нещасного випадку) є обов'язковим і здійснюється суб'єктами туристичної діяльності на підставі угод зі страховими компаніями, які мають право та ліцензію на таку діяльність.

Іноземні туристи, які прибувають в Україну, мають, зазвичай, обов'язкову, за законодавством країни проживання (крім країн СНД), медичну страховку або спеціально придбаний з нагоди туристичної поїздки страховий поліс.

Страхування в міжнародному туризмі - це основна форма гарантування страховими компаніями безпеки туристів у країні тимчасового перебування, покликана при настанні страхових випадків компенсувати можливу шкоду, заподіяну здоров’ю чи майну туристів, за рахунок страхових внесків, що сплачуються ними.

Страхування в туризмі - система взаємозв'язків між страховою компанією і туристом по забезпеченню захисту життя, здоров'я та майнових інтересів громадян під час туристичної подорожі. Спектр страхових послуг на туристичному ринку можна поділити на дві групи: особисте (страхування життя, страхування від нещасного випадку, медичне страхування) та інші види страхування. Особисте страхування в туристичній діяльності має першорядне значення, оскільки страхування від нещасного випадку та медичне страхування регламентовано українським законодавством та має обов'язковий характер. До інших видів страхування в туризмі можна віднести наступні:

$>$ Майнове страхування: Такий вид страхування в туризмі передбачає страхування приватного майна туриста на випадок втрати, крадіжки, пограбування, поломки або руйнування.

> Страхування відповідальності перед третіми особами. Поряд зі страхуванням майна договором страхування може бути так само передбачена відповідальність за шкоду, заподіяну життю, здоров'ю або майну третіх осіб внаслідок настання події, визнаної страховим випадком. Це можуть бути події, які відбулись в результаті дії вогню (виключаючи пожежу внаслідок підпалу); вибуху газу, що споживається для побутових потреб; пошкодження водою в результаті аварії систем водопостачання, каналізації, опалення і т.Д.

Страхування від нещзасного випадку: травматичне ушкодження, гостре отруєння отруйними рослинами, хімічними речовинами (промисловими або побутовими), ліками (крім випадків самолікування), утоплення, асфіксія внаслідок попадання сторонніх тіл або рідин у дихальні шляхи, укуси тварин, у тому числі змій, отруйних комах, захворювання кліщовим енцефалітом (енцефаломієлітом), правцем, ботулізмом, опіками, ураженнями блискавкою або електричним струмом, обмороження, переохолодження.Призначене для відшкодування збитку, викликаного втратою здоров'я або смертю застрахованого.

> Страхування від скасування туру. При страхуванні втрат від вимушеної відмови від поїздки страховим випадком $є$ подія, що спричинила виникнення у застрахованого витрат, пов'язаних з відміною поїздки або зміни термінів його перебування.

$>$ Страхування для автомобілістів. Відбувається через систему Зелена карта (англ. Green Card). Зелена карта - міжнародний договір (поліс) страхування автоцивільної відповідальності про взаємне визнання країнами - членами Угоди страхового поліса по страхуванню відповідальності власників засобів автотранспорту.

$>$ Страхування солідарної взаємодопомоги. Страхування за системою “Асістанс" - новий вид послуг на страховому ринку, який отримав широке поширення у світі завдяки своїй значній користі для туристів. Він забезпечує туристів або спеціалістів, відряджених за кордон, допомогою на місці в технічній (ремонт автомобіля), грошовій або іншій формі.

Ассистанс - від французького "assistance" - допомога. Компанія - ассистанс - сервісний центр, що надає інформаційні і організаційні послуги застрахованим в страхових компаніях приватним особам (страхувальникам). Ці послуги надаються громадянам, що знаходяться зовні меж основного місця проживання.

Розрізняють:

$>$ медичний ассистанс (медичне обслуговування, організація госпіталізації і лікування);

$>$ технічний ассистанс (технічна допомога на дорогах, організація доставки транспортних засобів, аварійний комісаріат, попередня оцінка збитку при ДТП);

$>$ юридичний ассистанс (юридична допомога i забезпечення правової підтримки);

$>$ інформаційний ассистанс;

$>$ туристичний ассистанс (пошук і бронювання готелів, візова підтримка, оренда автомобілів) і так далі.

Ассистанські компанії традиційно володіють розвиненою інфраструктурою для надання клієнту максимально швидкого і легкого доступу до всього комплексу послуг організаційного і інформаційного характеру, наприклад, центрами обслуговування, телефонними довідковими службами. Найбільші ассистанскі компанії надають допомогу в будь-якій точці земної кулі.

Різноманітність видів страхування, які використовуються на ринку туристичного страхування, обгрунтована неоднорідністю ймовірних ризиків, які можуть виникнути під час туристичної подорожі, зазвичай потрібно враховувати всі чинники. Характер таких ризиків може бути різним: фінансовим, майновим, медичним, юридичним або адміністративним. Зазна- 
чені ризики залежать від конкретного страхового випадку та заздалегідь враховуються у страховому полісі. Для того, щоб оформити страховку, необхідно купити страховий поліс, який буде запропонований страховою компанією споживачу. Для більш комфортного обслуговування клієнтів існують страхові програми (поліси), які позначаються кодами А, B, C, D.

\begin{tabular}{|c|c|}
\hline Літера & Комплекс послуг \\
\hline A & $\begin{array}{l}\text { Евакуація потерпілого в лікувальну установу і медичні витрати при нещасному випадку або } \\
\text { раптовому захворюванні }\end{array}$ \\
\hline B & $\begin{array}{l}\text { Евакуація потерпілого в лікувальну установу і медичні витрати при нещасному випадку або } \\
\text { раптовому захворюванні + оплата візиту родичів до застрахованого та надання стоматологічної } \\
\text { допомоги }\end{array}$ \\
\hline $\mathrm{C}$ & $\begin{array}{l}\text { Евакуація потерпілого в лікувальну установу і медичні витрати при нещасному випадку або } \\
\text { раптовому захворюванні + оплата візиту родичів до застрахованого та надання стоматологічної } \\
\text { допомоги }+ \text { юридична допомога (можливість зв’язатися із адвокатом) та адміністративна } \\
\text { допомога (повернення неправильно відправленого багажу, оформлення нових документів замість } \\
\text { загублених і т. д.) }\end{array}$ \\
\hline D & $\begin{array}{l}\text { Евакуація потерпілого в лікувальну установу і медичні витрати при нещасному випадку або } \\
\text { раптовому захворюванні + оплата візиту родичів до застрахованого та надання стоматологічної } \\
\text { допомоги + юридична допомога (можливість зв’язатися із адвокатом) та адміністративна } \\
\text { допомога (повернення неправильно відправленого багажу, оформлення нових документів замість } \\
\text { загублених і т. д.) + послуги при поломці особистого автотранспорту або при хворобі водія }\end{array}$ \\
\hline
\end{tabular}

Страховим полісом повинні передбачатися оплата медичної допомоги туристам і відшкодування їх витрат при настанні страхового випадку безпосередньо в країні (місці) тимчасового перебування.

Страховий поліс туриста (Travel Insurance Policy) є номерним бланком строгої звітності. На паспортній частині поліса, тобто на його обкладинці, повністю указуються назва страхової компанії і їі зарубіжної сервісної компанії (Medical Assistance Company). В основній частині поліса проставляються реквізити страхувальника, ім'я, прізвище, дата народження туриста, територія дії поліса (країна), розмір страхової суми, розмір невідшкодованого збитку (франшиза), об'єкт страхування, приводяться правила страхування, детально описуються ризики, за які страхова компанія відповідає, а також інші умови, за угодою сторін і ставляться підписи страхувальника і туриста.

Укладаючи договір з туристичною фірмою, страхові компанії для обслуговування туристів і відпочиваючих за кордоном, включають в страхову програму подорожуючого широкий асортимент послуг із страхування:

> при раптовому захворюванні - невідкладну медичну допомогу, амбулаторне і стаціонарне лікування, у тому числі операцію, в першокласних клініках;

$>\quad$ екстрену стоматологічну допомогу (при гострому зубному болі) в розмірі не більше 200 дол. США;

$>$ надання медичного устаткування (інвалідні коляски і ін.);

$>$ термінову доставку одного з найближчих родичів до місця події і назад;

$>\quad$ екстрене повернення потерпілого на батьківщину разом з супроводжуваною особою, якщо це необхідне за медичними показаннями. У летальних випадках страхова компанія оплачує всі витрати по репатріації тіла туриста на батьківщину;
$>$ забезпечення засобами для повернення додому неповнолітніх дітей, мандрівників та потерпілих туристів;

$>\quad$ сприяння в організації кваліфікованої юридичної допомоги і його захисту застрахованому;

$>\quad$ оплату термінових повідомлень, пов'язаних із страховим випадком.

У страховому полісі також вказуються випадки, коли страховик не відшкодовує понесені туристом витрати, якщо вони не відносяться до страхових випадків.

Не є страховими випадками:

$>$ хронічні захворювання;

$>$ сонячні і теплові опіки;

$>$ захворювання, пов'язані з вживанням і одержаних в результаті вживання алкоголю і наркотичних засобів;

$>$ захворювання, викликані невиправданим ризиком (спуск в печери, стрибки у воду з трампліну і т.д.);

$>$ захворювання або нещасні випадки, що відбулися до або після повернення застрахованого в країну постійного мешкання;

$>\quad$ пластична хірургія, різного роду протезування, щеплення, профілактичні вакцинації і т.д.;

$>$ тілесні пошкодження при участі в страйках, військових діях;

$>$ умисне нанесення собі тілесних пошкоджень;

$>$ випадки самогубств;

$>$ витрати на додатковий комфорт (телевізор, телефон, кондиціонер, послуги масажиста або косметолога), якщо турист перебуває в лікарні. 


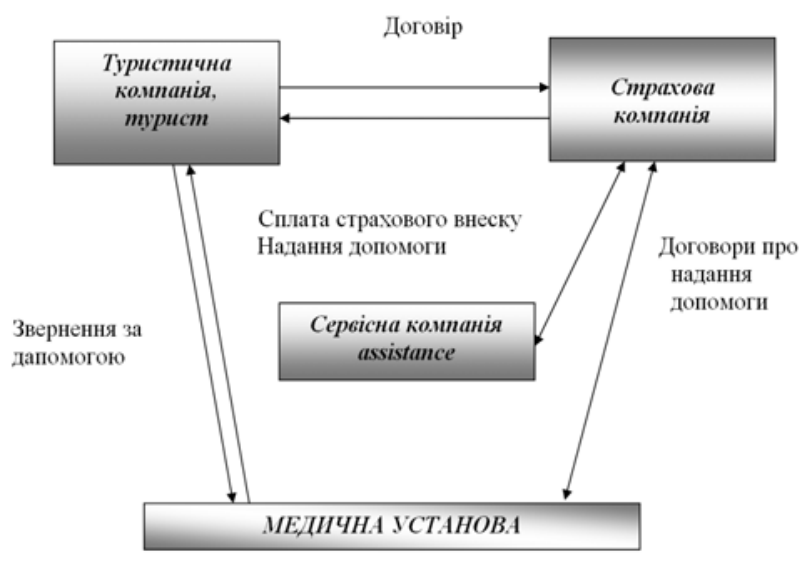

Рис.1. Схема надання медичної допомоги туристу відповідно до медичного договору

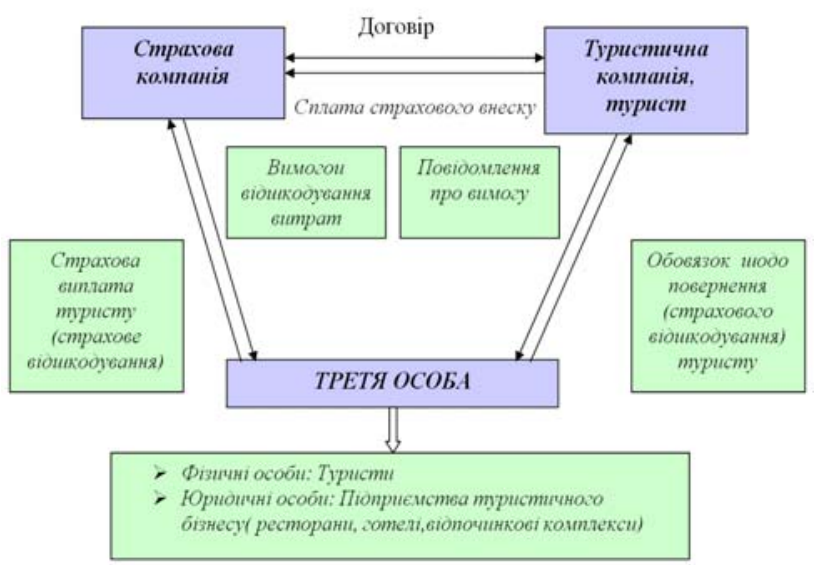

Рис. 2. Схема взаємодії субєктів страхування відповідальності

\section{Висновки}

Відправляючись в туристичну чи екскурсійну поїздку, на відпочинок , оздоровлення, або у всесвітню подорож, турист стикається $з$ цілою низкою проблем, які при збігу обставин можуть призвести до негатив- них наслідків для його здоров'я та майна, погано вплинути на настрій та враження від поїздки.

Перебуваючи в незнайомому середовищі, яке відрізняється від місця постійного проживання, активно відпочиваючи, турист постійно знаходиться під впливом ризикових обставин. Він не знає досконало звичаїв, мови, традицій, побуту, не має імунітету від хвороб, поширених у даній місцевості, не пристосований до проживання та інтенсивних навантажень у гірських районах, в пустелі або на воді.

Суб'єкти туристичної діяльності розробляють конкретні заходи щодо забезпечення безпеки туристів, екскурсантів, які беруть участь у туристичних подорожах запобігання травматизму та нещасним випадкам і несуть відповідальність за їх виконання. Зважаючи на поширення страхування в галузі туризму, можна прогнозувати підвищення ролі інших страхових продуктів, які стосуються захисту від майнових та фінансових ризиків, які виникають в українського туриста при виїзді за кордон.

Отже, для підвищення рівня безпеки туриста, його життя та здоровя, поширення привабливості страхування та удосконалення туристичних продуктів всім учасникам організації туристичної подорожі доцільно було б розширювати спектр страхових послуг. Прозора і доступна позиція всіх зацікавлених сторін $є$ необхідною умовою успішного розвитку туристичного страхування в країні.

\section{References}

Aleksandrova, A.Ju. (2008). Mezhdunarodnyj turizm. Uchebnoe posobie dlja vuzov. Moskva: Aspekt Press (in Russian).

Marinin, M.M. (2008). Turisticheskie formal'nosti i bezopasnost' v turizme. Ucheb. posobie. M.: Finansy i statistika (in Russian).

Sirik, N.V. (2006). Imushhestvennoe strahovanie V turizme. Vestnik OGU, 3, 163-166. Rezhim dostupa: http://vestnik.osu.ru/2006_3/34.pdf(in Russian). 